\title{
Modeling of recipes of special purpose bakery products
}

\author{
Ainash Rustemova ${ }^{1, *}$, Nurudin Kydyraliev ${ }^{2}$, Tatyana Kirillova ${ }^{3}$, Madina Sadygova ${ }^{3}$, and Nurgul Batyrbayeva ${ }^{1}$ \\ ${ }^{1}$ Almaty Technological University, 050012 Almaty, Kazakhstan \\ 2 Kyrgyz-Turkish Manas University, 720038 Bishkek, Kyrgyzstan \\ ${ }^{3}$ Saratov State Agrarian University named after N.I. Vavilov, 410012 Saratov, Russia
}

\begin{abstract}
In this article the results of calculations of experimental-statistical methods are given, using the optimized contents of components in "Puff buns" and "Grain bars" recipes. The proposed products are balanced in the content of nutrients (proteins, fats, carbohydrates), contain a wide range of vitamins and essential amino acids, which allows expanding the consumer food market and more efficiently using vegetable resources. In order to obtain the percentage ratio of the components in the flour products composition, the complete factor experiment - a central compositional rotatable planning experiment - was applied. According to the results of mathematical modeling for "Puff buns", the optimal percentage ratio of rice bioflour and pumpkin was chosen as 20:20, for "Grain bar" the optimal dosage of mashed bananas and Jerusalem artichoke is $28: 12$ respectively.
\end{abstract}

\section{Introduction}

Food products design is a process of creation rational recipes that can provide a high level of adequacy of the complex of properties of food products to the consumers' requirements and to the standardized values of nutrients and energy content [1-7]. According to the modern views, the term design of products includes the development of models that describes steps of products creation using the given quality. It also represents mathematical dependence of changing one or several key parameters on which base they are being developed, including the optimization of choice and the ratio of components [8-11].

Purpose of the study - ingredients' optimization in bakery products' recipe - "Puff buns", "Grain bars" which by quantitative content and quality composition will match the formula of balanced diet, as much as possible, meet biomedical requirements and own high consumer properties.

\section{Materials and research methods}

The optimization of the prescribed composition of "Puff buns", "Cereal bars" was performed by experimental statistical methods. To construct the mathematical models of function dependency, the response of input factors, we used central compositional rotable planning of the experiment (CCRP).

The regression equation with two variables in central compositional rotable planning is presented as the second order equation:

$$
Y=b_{o}+b_{1} X_{1}+b_{2} X_{2}+b_{12} X_{1} X_{2}+b_{11} X_{1}^{2}+b_{22} X_{2}^{2} .
$$

The number of experiments using CCRP in the twofactor experiment $(n=2)$ equals $\mathrm{N}=13$. To the full factor experiment $2^{2}$ let us add 5 experiments in centre of the plan and four "star" points with coordinates $(+a ; 0)$; $(-$ $a ; 0) ;(0 ;+a)$; and $(0 ;-a)$.

Using CCRP for the regression equations ` coefficients (1) and relevant marks of dispersions, we use formulas from the tutorial [12].

\section{Results and discussion}

The grafic interpritation of the regression equation is response surface. Analysis of two-dimensional sections of response surface allows preliminarily determining areas of factor space, where we achieved an optimal value of output parameters. Figures 1-16 show a graphic picture of regression models as paraboloids and a two-dimensional section of paraboloids.

The comparison of estimated values of the Student criterion with the table at a significance level of $\alpha=0,05$ and the number of degrees of freedom $\mathrm{N}\left(\mathrm{n}_{0}-1\right)=16$ $\left(t_{m}=1.7459\right)$ allows choosing significant regression coefficients.

Table values of the Fisher criterion at a significance level of $\alpha=0,05$ and the number of degrees of freedom of numerator $\ddot{f}_{1}=3$ and denominator $\ddot{f}_{2}=4$ equal $\mathrm{F}_{\mathrm{T}}=$ 6.59. The comparison of the Fisher criterion estimated value and table shows that regression equations are adequate to experimental data.

\footnotetext{
Corresponding author: aist_2707@mail.ru
} 
Table 1. Planning matrix and results of the experiment «Grain bars».

\begin{tabular}{|c|c|c|c|c|c|c|c|c|}
\hline \multirow[t]{2}{*}{$\begin{array}{c}\text { № of } \\
\text { experiment }\end{array}$} & \multicolumn{2}{|c|}{$\begin{array}{l}\text { Coded values of } \\
\text { factors }\end{array}$} & \multicolumn{2}{|c|}{$\begin{array}{l}\text { Natural values of } \\
\text { factors }\end{array}$} & \multicolumn{4}{|c|}{ Response function } \\
\hline & $X_{1}$ & $X_{2}$ & $\begin{array}{c}X_{l,} \\
\text { Jerusalem } \\
\text { artichoke } \\
\text { content, \% }\end{array}$ & $\begin{array}{c}X_{2}, \\
\text { Banana } \\
\text { content, \% }\end{array}$ & $\begin{array}{c}Y_{l,} \text { mass } \\
\text { fraction of } \\
\text { protein, } \%\end{array}$ & $\begin{array}{c}Y_{2 .}, \text { mass } \\
\text { fraction of } \\
\text { cellulose, \% }\end{array}$ & $\begin{array}{c}Y_{3}, \\
\text { antioxidant } \\
\text { activity, } \\
\mathrm{mg} / 100 \mathrm{~g}\end{array}$ & $\begin{array}{l}Y_{4} \text {, complex } \\
\text { point mark }\end{array}$ \\
\hline 1 & -1 & -1 & 5 & 20 & 6,0 & 4,9 & 29 & 69 \\
\hline 2 & +1 & -1 & 16 & 20 & 6,8 & 5,95 & 31 & 70 \\
\hline 3 & -1 & +1 & 5 & 32 & 7,2 & 5,3 & 31,4 & 78 \\
\hline 4 & +1 & +1 & 16 & 32 & 7,5 & 6.16 & 32,5 & 74 \\
\hline 5 & 0 & $-1,414$ & 10,5 & 17,516 & 6,0 & 4,8 & 28,1 & 80 \\
\hline 6 & $-1,414$ & 0 & 2,723 & 26 & 6,8 & 5,1 & 31,0 & 62 \\
\hline 7 & 0 & $+1,414$ & 10,5 & 34,484 & 7,2 & 6.29 & 32,5 & 78 \\
\hline 8 & $+1,414$ & 0 & 18,277 & 26 & 7,0 & 6.0 & 30,5 & 71 \\
\hline 9 & 0 & 0 & 10,5 & 26 & 6,0 & 6,1 & 28.7 & 95 \\
\hline 10 & 0 & 0 & 10,5 & 26 & 6,0 & 6,1 & 28.7 & 95 \\
\hline 11 & 0 & 0 & 10,5 & 26 & 6,0 & 6,1 & 28.7 & 95 \\
\hline 12 & 0 & 0 & 10,5 & 26 & 6,0 & 6,1 & 28.7 & 95 \\
\hline 13 & 0 & 0 & 10,5 & 26 & 6,0 & 6,1 & 28.7 & 95 \\
\hline
\end{tabular}

Table 2. Dependences of response function of input factors «Grain bars».

\begin{tabular}{|c|c|}
\hline $\begin{array}{c}\text { Response } \\
\text { function }\end{array}$ & Regression equation \\
\hline $\begin{array}{c}\mathrm{Y}_{1,-} \text { mass } \\
\text { fraction of } \\
\text { protein, \% }\end{array}$ & $Y_{1}=6,00+0,45 X_{2}+0,39 X_{1}^{2}+0,24 X_{2}^{2}$ \\
\hline $\begin{array}{c}\mathrm{Y}_{2}, \text { mass } \\
\text { fraction of } \\
\text { cellulose, } \%\end{array}$ & $Y_{2}=6,03+0,4 X_{1}+0,34 X_{2}-0,28 X_{1}^{2}-0,29 X_{2}^{2}$ \\
\hline $\begin{array}{c}\mathrm{Y}_{3}, \\
\text { antioxidant } \\
\text { activity, } \\
\text { mg/100 g }\end{array}$ & $Y_{3}=28,18+0,9 X_{1}+0,52 X_{1}^{2}+1,479 X_{2}^{2}$ \\
\hline $\begin{array}{c}\mathrm{Y}_{4}, \text { complex } \\
\text { point mark }\end{array}$ & $Y_{4}=94,35-3,55 X_{1}+0,39 X_{1} X_{2}-12,342 X_{1}^{2}-10,63$ \\
\hline
\end{tabular}

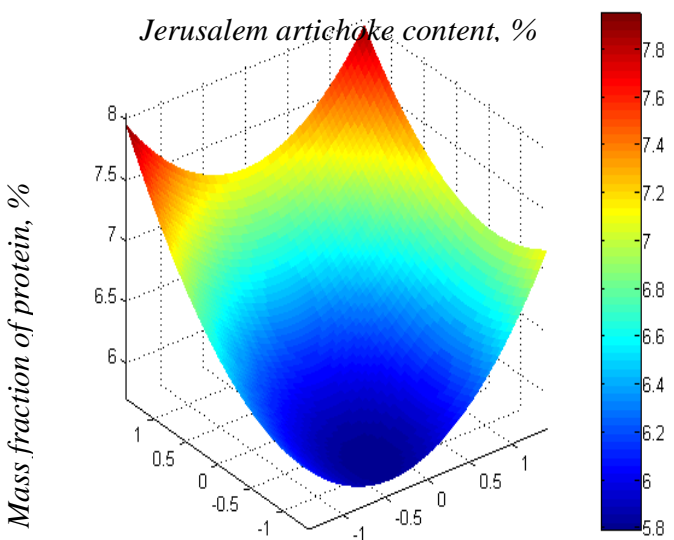

Fig. 1. General form of response surface $Y_{1}$

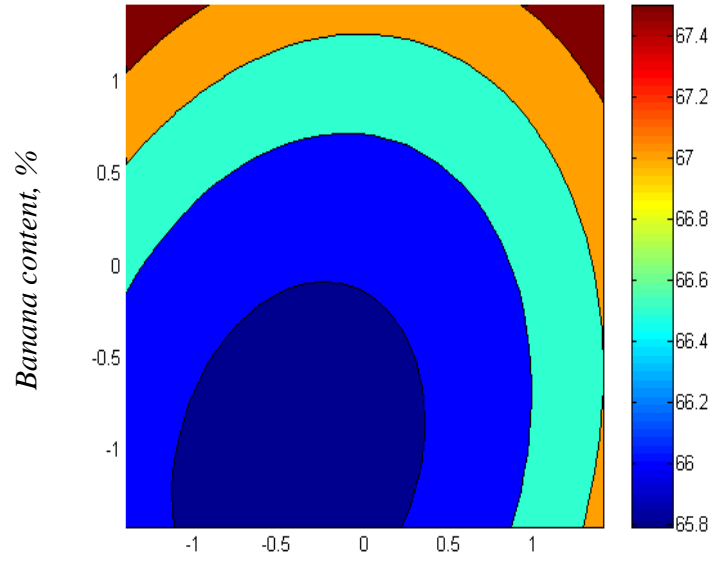

Fig. 2. Two-dimensional section of response $Y_{1}$.

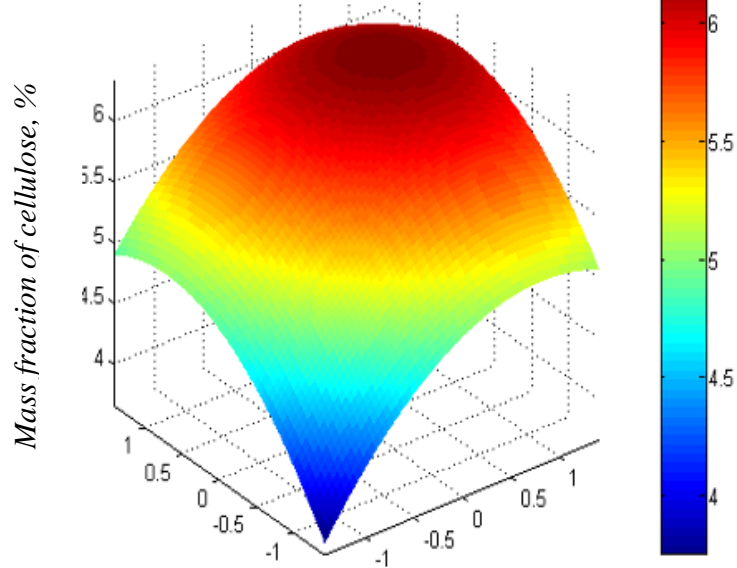

Fig. 3. General form of response surface $\mathrm{Y}_{2}$. 


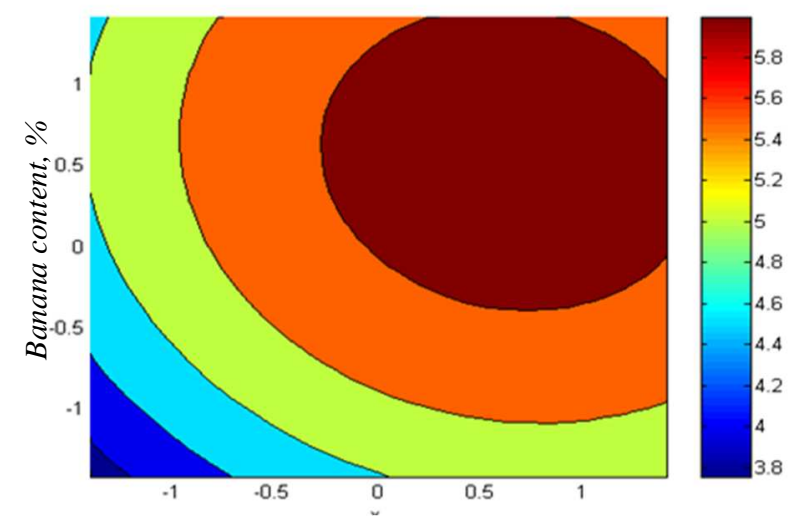

Fig. 4. Two-dimensional section of response surface $\mathrm{Y}_{2}$.

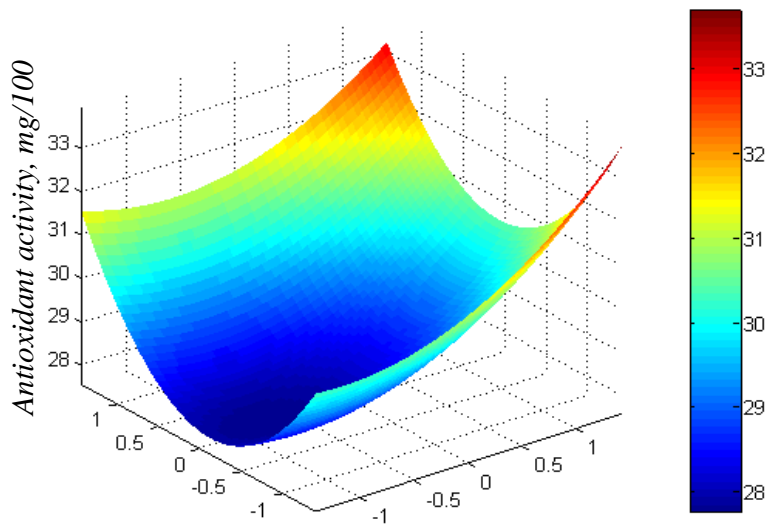

Fig. 5. General form of response surface $Y_{3}$.

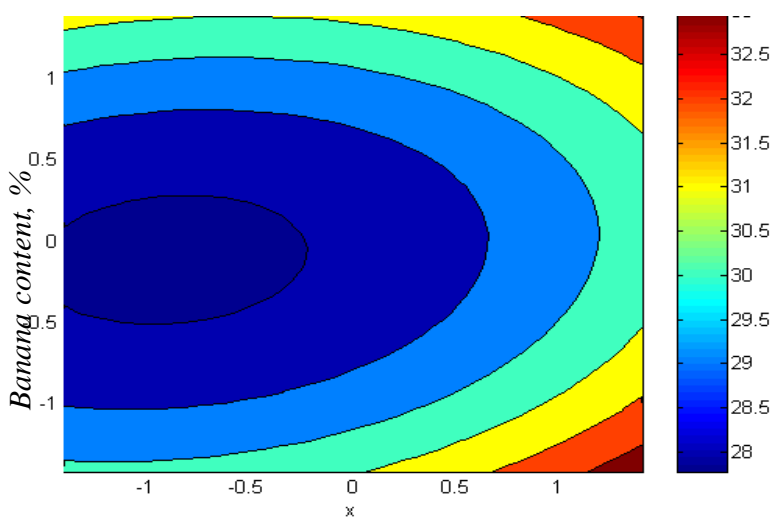

Jerusalem artichoke content, \%

Fig. 6. Two-dimensional section of response surface $\mathrm{Y}_{3}$.

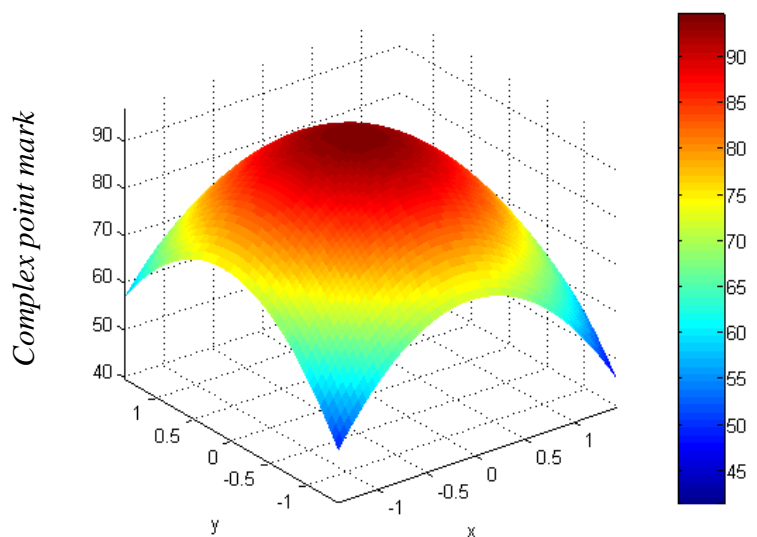

Fig. 7. General form of response surface $\mathrm{Y}_{4}$.

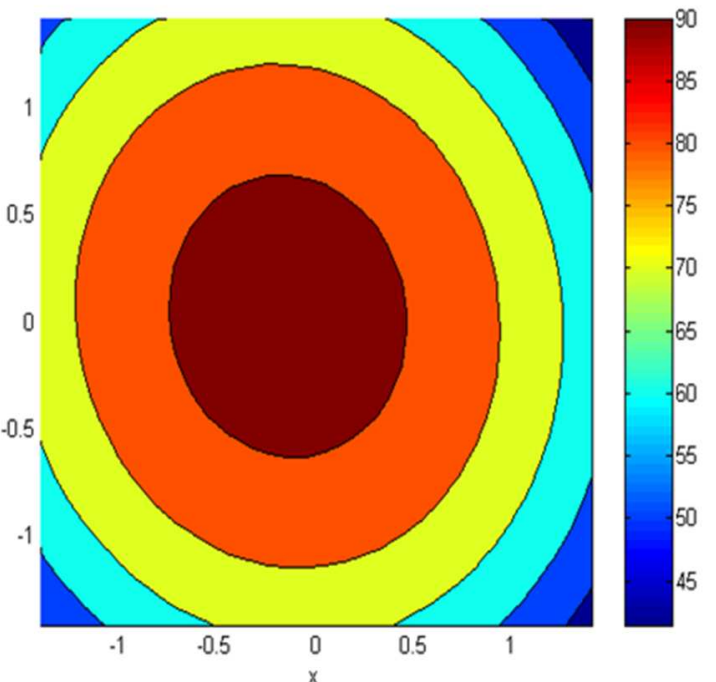

Jerusalem artichoke content,, \%

Fig. 8. Two-dimensional section of response surface $\mathrm{Y}_{4}$.

Table 3. Planning matrix and results of the experiment «Puff buns».

\begin{tabular}{|c|c|c|c|c|c|c|c|c|}
\hline \multirow[b]{2}{*}{ 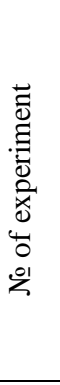 } & \multicolumn{2}{|c|}{$\begin{array}{c}\text { Coded values } \\
\text { of factors }\end{array}$} & \multicolumn{2}{|c|}{$\begin{array}{c}\text { Natural values } \\
\text { of factors }\end{array}$} & \multicolumn{4}{|c|}{ Response function } \\
\hline & $X_{1}$ & $X_{2}$ & 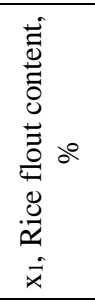 & 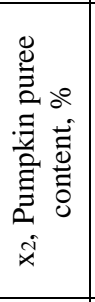 & 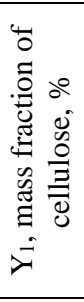 & 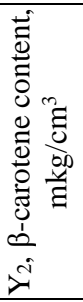 & 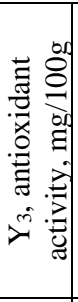 & 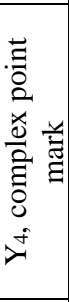 \\
\hline 1 & -1 & -1 & 10,0 & 10,0 & 2,06 & 2,8 & 84 & 69 \\
\hline 2 & +1 & -1 & 20,0 & 10,0 & 2,27 & 2,8 & 84 & 70 \\
\hline 3 & -1 & +1 & 10,0 & 20,0 & 2,30 & 3,3 & 92 & 78 \\
\hline 4 & +1 & +1 & 20,0 & 20,0 & 2,39 & 3,31 & 93 & 100 \\
\hline 5 & 0 & $-1,414$ & 15 & 7,93 & 2,12 & 2,6 & 81 & 80 \\
\hline 6 & $-1,414$ & 0 & 7,93 & 15 & 1,98 & 3,02 & 88 & 62 \\
\hline 7 & 0 & $+1,414$ & 15 & 22,07 & 2,32 & 3,4 & 90 & 78 \\
\hline 8 & $+1,414$ & 0 & 22,07 & 15 & 2,44 & 3,0 & 91 & 71 \\
\hline 9 & 0 & 0 & 15,0 & 15,0 & 2,22 & 3,11 & 89 & 90 \\
\hline 10 & 0 & 0 & 15,0 & 15,0 & 2,22 & 3,11 & 89 & 90 \\
\hline 11 & 0 & 0 & 15,0 & 15,0 & 2,22 & 3,11 & 89 & 90 \\
\hline 12 & 0 & 0 & 15,0 & 15,0 & 2,22 & 3,11 & 89 & 91 \\
\hline 13 & 0 & 0 & 15,0 & 15,0 & 2,22 & 3,11 & 89 & 90 \\
\hline
\end{tabular}


Table 4. Results of coefficients significant check of models and the adequacy of the regression equation «Puff buns».

\begin{tabular}{|c|c|c|c|c|c|c|c|c|c|c|c|c|}
\hline .气̊ี & $\begin{array}{l}\text { Valu } \\
\text { coeff }\end{array}$ & $\begin{array}{l}\text { de } \\
\text { ficien }\end{array}$ & ats & & of & $\begin{array}{l}\text { Estim } \\
\text { Stude }\end{array}$ & $\begin{array}{l}\text { nated } \\
\text { ent cr }\end{array}$ & $\begin{array}{l}1 \text { valu } \\
\text { riterio }\end{array}$ & $\begin{array}{l}\text { ue of } \\
\text { on }\end{array}$ & & & $\begin{array}{l}\breve{o} \\
\varrho \\
\varrho\end{array}$ \\
\hline 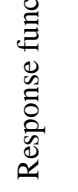 & \begin{tabular}{|l|l|l}
$b_{o}$ & $b_{1}$ \\
\end{tabular} & \begin{tabular}{l|l}
1 & $b_{2}$
\end{tabular} & $b_{12}$ & & $b_{22} \mid t$ & \begin{tabular}{l|l}
$t_{b_{0}}$ & $t_{b_{1}}$
\end{tabular} & $t_{b_{2}}$ & $\left|t_{b_{12}}\right| t$ & \begin{tabular}{l|l|l}
$t_{b_{11}}$ & $t_{b_{2}}$
\end{tabular} & & 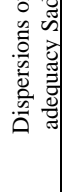 & 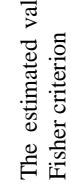 \\
\hline 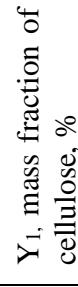 & & & $\begin{array}{ll}0 \\
0\end{array}$ & & & ते & 09 & d) & & of & 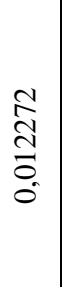 & $\begin{array}{l}\text { ठิ } \\
\text { సิ } \\
\text { กิ }\end{array}$ \\
\hline 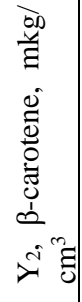 & ते & gृ & ㄱ. & & & $\begin{array}{l}\text { of } \\
\text { of }\end{array}$ & & a) & & 격 & 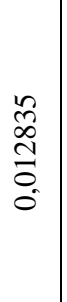 & 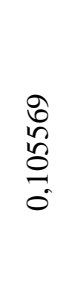 \\
\hline 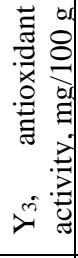 & $\begin{array}{l}9 \\
0 \\
\infty\end{array}$ & 글 & งู ปู & & an & ती & $\begin{array}{cc}0 \\
0\end{array}$ & 영 & & 가 & 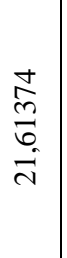 & 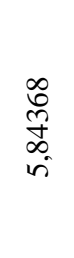 \\
\hline 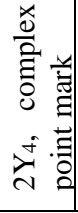 & 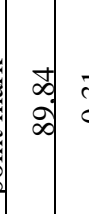 & 今. & ?. & & & वी & 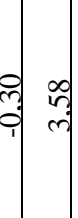 & 웅 & वे & ते & 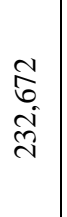 & 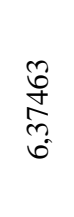 \\
\hline
\end{tabular}

Table 5. Dependences of the response function of input factors «Puff buns».

\begin{tabular}{|l|l|}
\hline $\begin{array}{l}\text { Response } \\
\text { function }\end{array}$ & Regression equation in coded variable \\
\hline $\begin{array}{l}\mathrm{Y}_{1}, \text { mass fraction } \\
\text { of cellulose, } \%\end{array}$ & $Y_{1}=2,40+0,12 X_{1}-0,11 X_{1}^{2}-0,10 X_{2}^{2}$ \\
\hline $\begin{array}{l}\mathrm{Y}_{2}, \quad \beta \text {-carotene, } \\
\mathrm{mkg} / \mathrm{cm}^{3}\end{array}$ & $Y_{2}=3,20+0,27 X_{2}-0,11 X_{1}^{2}-0,12 X_{2}^{2}$ \\
\hline $\begin{array}{l}\mathrm{Y}_{3}, \text { antioxidant } \\
\text { activity, mg/100g }\end{array}$ & $Y_{3}=88,10+1,36 X_{1}+2,29 X_{2}-2,41 X_{1}^{2}+0,55 X_{2}^{2}$ \\
\hline $\begin{array}{l}\mathrm{Y}_{4}, \quad \text { complex } \\
\text { point mark }\end{array}$ & $Y_{4}=89,84_{1}+3,63 X_{2}+5,23 X_{1} X_{2}-8,49 X_{1}^{2}-6,79 X_{2}^{2}$ \\
\hline
\end{tabular}

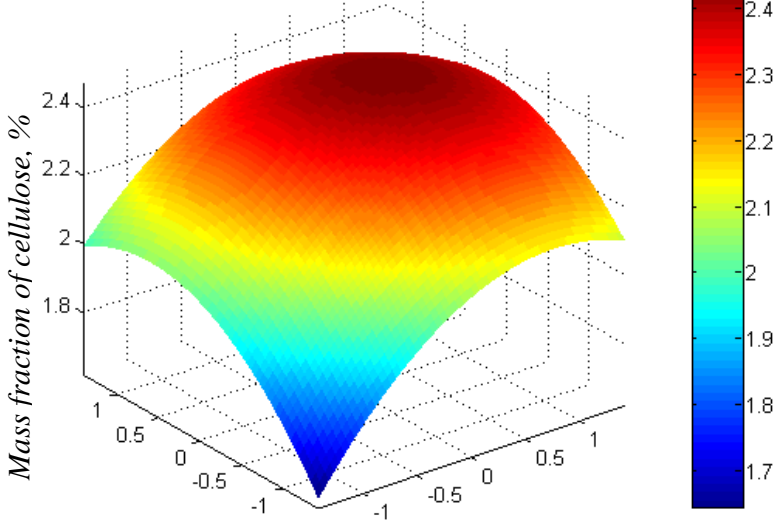

Fig. 9. General form of response surface $\mathrm{Y}_{1}$.

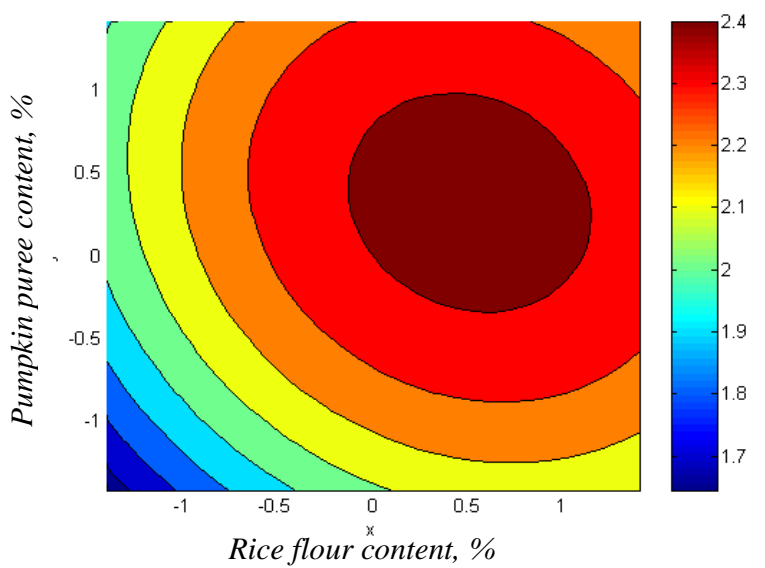

Fig. 10. Two-dimensional section of response surface $Y_{1}$.

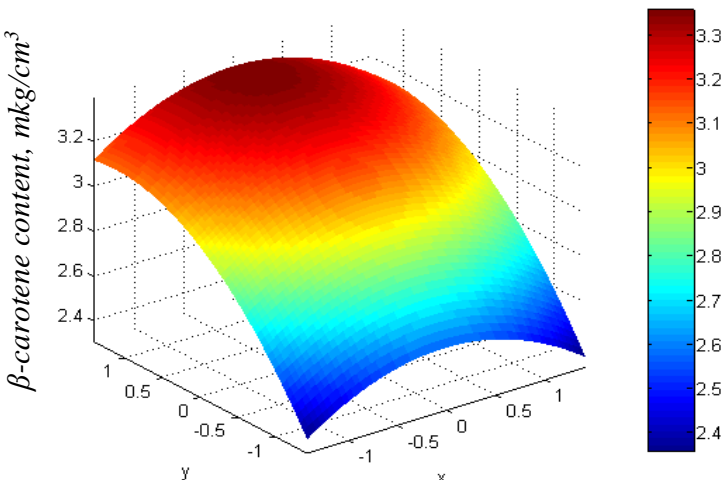

Fig. 11. General form of response surface $Y_{2}$.

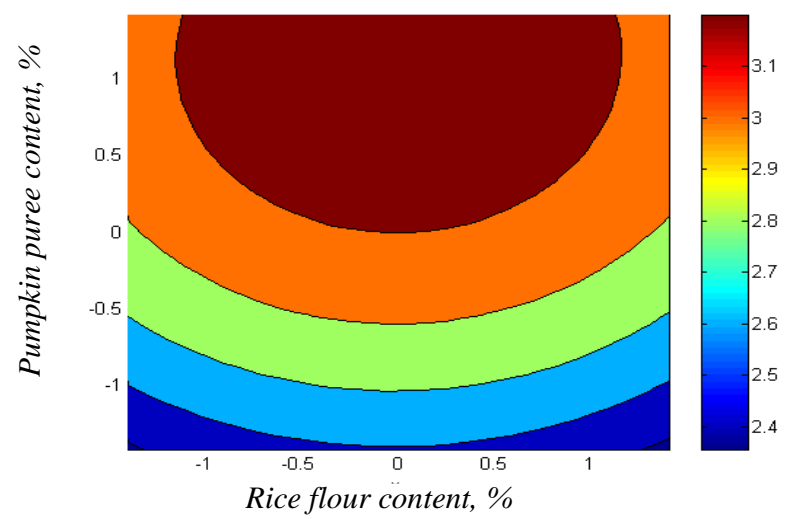

Fig. 12. Two-dimensional section of response surface $\mathrm{Y}_{2}$. 


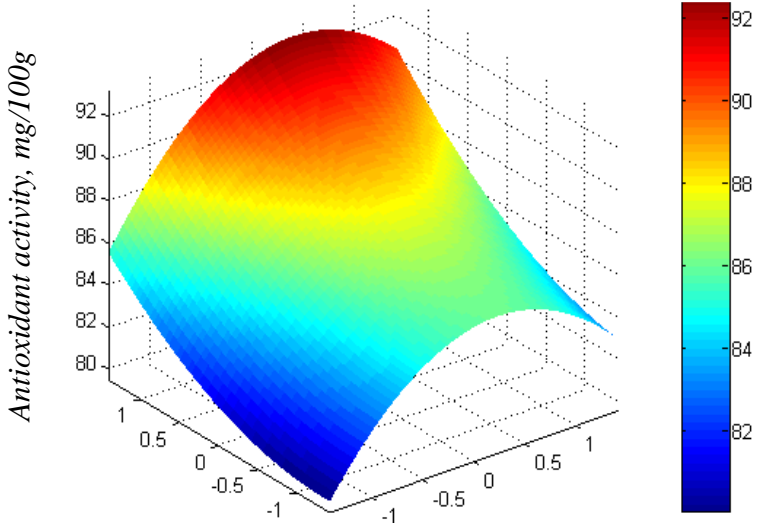

Fig. 13. General form of response surface $Y_{3}$.

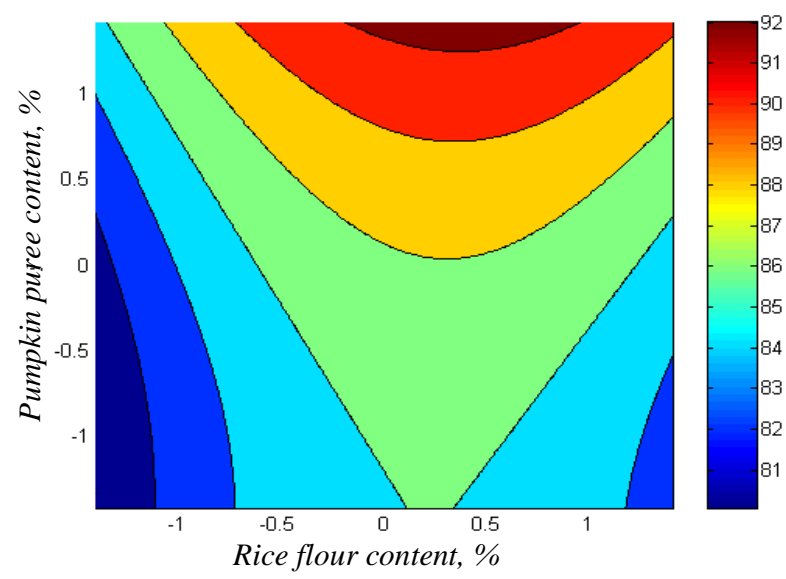

Fig. 14. Two-dimensional section of response surface.

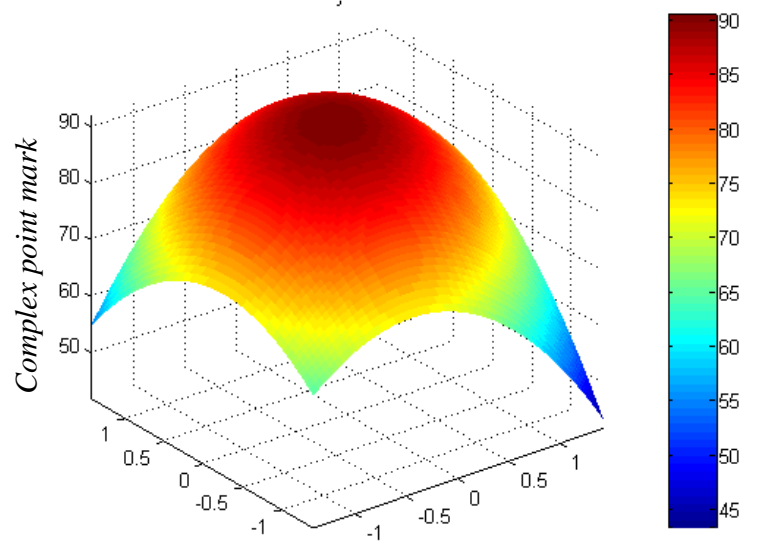

Fig. 15. General form of response surface $\mathrm{Y}_{4}$.

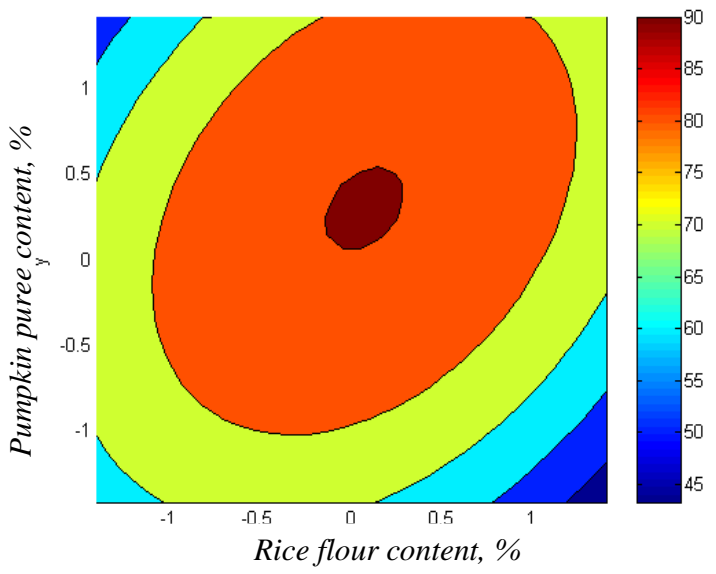

Fig. 16. Two-dimensional section of response surface $\mathrm{Y}_{4}$.
Built regression models may be used for recipe optimization of «Cereal bars», «Puff buns».

For the ratio of components determination in the «Cereal bars» recipe, let`s build a mathematical model of optimization by four criteria:

$$
\begin{gathered}
6,00+0,45 X_{2}+0,39 X_{1}^{2}+0,24 X_{2}^{2} \rightarrow \operatorname{miax} ; \\
6,03+0,4 X_{1}+0,34 X_{2}-0,28 X_{1}^{2}-0,29 X_{2}^{2} \rightarrow \max ; \\
28,18+0,9 X_{1}+0,52 X_{1}^{2}+1,479 X_{2}^{2} \rightarrow \max x \\
94,35-3,55 X_{1}+0,39 X_{1} X_{2}-12,342 X_{1}^{2}-10,63 X_{2}^{2} \rightarrow \max \\
\text { while limiting } \quad X_{1}^{2}+X_{2}^{2} \leq 2
\end{gathered}
$$

here $X_{1}, X_{2}-$ coded values of factors, related with natural values $x i$ by ratios:

$$
X_{1}=\frac{x_{1}-10,5}{5,5} ; \quad X_{2}=\frac{x_{2}-26}{6} \text {. }
$$

For determination of the components ratio in the recipe of «Puff buns» let`s build a mathematical model of optimization by four criteria:

$$
\begin{gathered}
2,40+0,12 X_{1}-0,11 X_{1}^{2}-0,10 X_{2}^{2} \rightarrow \max ; \\
3,20+0,27 X_{2}-0,11 X_{1}^{2}-0,12 X_{2}^{2} \rightarrow \max ; \\
88,10+1,36 X_{1}+2,29 X_{2}-2,41 X_{1}^{2}+0,55 X_{2}^{2} \rightarrow \max x ; \\
89,84_{1}+3,63 X_{2}+5,23 X_{1} X_{2}-8,49 X_{1}^{2}-6,79 X_{2}^{2} \rightarrow \max \\
\text { while limiting } \quad X_{1}^{2}+X_{2}^{2} \leq 2 ;
\end{gathered}
$$

here $X_{1}, X_{2}-$ coded values of factors, related with natural values $x i$ by ratios: $X_{1}=\frac{x_{1}-15}{5} ; \quad X_{2}=\frac{x_{2}-15}{5}$.

The task of multi-criteria optimization by the target programming method transformation into a mono-criteria task of minimization of the number of deviations with some indicator $p$ :

$$
G=\left(\sum_{k=1}^{K} w_{k}\left|\frac{f_{k}(x, y, z)-\bar{f}_{k}}{\bar{f}_{k}}\right|^{p} \rightarrow \min ,\right.
$$

where $w_{k}$ - some weight coefficients that characterize the importance of one or other criterion, $\bar{f}_{1}, \bar{f}_{2}, \ldots, \bar{f}_{K}$ values of target functions on the optimal plan for each criteria, $p$ - parameter, $k$ - number of target functions.

At $p=2$ and $w_{k}=1$ we get the following task of minimization of the amount and limitations:

$$
G=\left(\sum_{k=1}^{4} w_{k}\left|\frac{f_{k}(x, y, z)-\bar{f}_{k}}{\bar{f}_{k}}\right|^{2}\right)^{\frac{1}{2}} \rightarrow \min X_{1}^{2}+X_{2}^{2} \leq 2
$$

where $\bar{f}_{1}-$ maximum of the first criterion, $\bar{f}_{2}-$ maximum of the second criterion. $\bar{f}_{3}$ - maximum of the third criterion, $\bar{f}_{4}-$ maximum of the fourth criterion.

According to the results of the calculations, experimental and statistical methods optimized the contents of the components in the formulation of the 
developed products, which are confirmed by the results of trial laboratory baking.

The optimal solution of the single criterion task is point $x_{1}=12, x_{2}=28$.

The optimal dose of banana and Jerusalem artichoke puree is $28 \%$ and $12 \%$ respectively.

The optimal solution of the single criterion task is point $x_{1}=20, x_{2}=20$.

The optimal dose of rice flour and pumpkin puree is $20 \%$ and $20 \%$ respectively.

\section{Conclusion}

Thus, the presented results of mathematical modeling of recipes "Grain bars" and "Puff buns", based on the use of raw materials with different chemical composition and functional and technological properties, make it possible to obtain the ratio of recipe components, providing high organoleptic and physicochemical indicators of specialized products.

\section{References}

1. M.Sh. Suleimenova, A.Zh. Rustemova, Modern approaches to the development of technology for producing cereal bars, in: Materials of the AllRussian Scientific-Practical Conference with international participation Physical and colloidal chemistry - the basis of new technologies and modern methods of analysis in the chemical and food industries, pp. 71-77 (VSUIT, Voronezh, 2016)

2. V.V. Masalova, N.P. Oboturova, Prospects for the use of gluten-free plant materials in the production of food products for dietary and preventive nutrition, Food industry, 3, 16-20 (2016)

3. A.N. Shishkina, M.K. Sadygova, M.V. Belova, A.N. Astashov, Z.I. Ivanova, Use of secondary raw material of animal products in the technology of production of bakery products based on wheat amaranth mixture, Scientific Study \& Research Chemistry \& Chemical Engineering, Biotechnology, Food Industry, 20(2), 303-311 (2019)
4. T.N. Tertychnaya, V.I. Manzhesov, E.A. Andrianov, S.F. Yakovleva, New aspects of application of microalgae dunaliella salina in the formula of enriched bread, IOP Conference Series: Earth and Environmental Science, 012021 (2020)

5. S.V. Zverev, O.V. Politukha, I.A. Pankratieva, S.V. Bobkov, M.V. Donskaya, Fortification of chickpeas with cereals from cereals, Bakery products, 2, 42-45 (2020)

6. A.A. Ilchenko, A.A. Galiullin, Increasing the nutritional value of custard using pumpkin puree, in: Innovative technologies in agribusiness: theory and practice. Collection of articles of the VII All-Russian Scientific and Practical Conference, pp. 22-27 (Penza State Agrarian University, 2019)

7. I.P. Pastukhov, The study of the influence of inulin on the quality of shortbread cookies, in: Innovative ideas of young researchers for the agricultural sector of Russia. Collection of materials of the International scientific-practical conference of young scientists, pp. 203-205 (Penza State Agrarian University, 2019)

8. A.Yu. Krivosheev, Development of technology and a new assortment of achloride bakery products using directed enzyme compositions, candidate dissertation (VGUIT, Voronezh, 2018) 210 p.

9. D.V. Grashchenkov, Mathematical modeling of formulations for the organization of children's nutrition, Food industry, 3(4), 66-73 (2018) DOI 10.29141 / 2500-1922-2018-3-4-8

10. E.A. Marinina, M.K. Sadigova, T.V. Kirillova, I.Yu. Kanevskaya, Optimization of the recipe for biscuit cake mix, Technique and technology of food production, 1(50), 44-51 (2020)

11. M.K. Sadigova, T.V. Kirillova, I.Yu. Kanevskaya, Optimization of the content of dietary fiber in the formulation of a bakery product by regression analysis, in: XXI century: the results of the past and the problems of the present plus, 1(49)(9), 135-140 (2020)

12. N.M. Derkanosova, A.A. Zhuravlev, I.A. Sorokina, Modeling and optimization of technological processes of food production. Workshop (VGTA, Voronezh, 2011) $196 \mathrm{p}$. 